INTUISI 12 (1) (2020)
INTUISI
JURNAL PSIKOLOGI ILMIAH
http://journal.unnes.ac.id/nju/index.php/INTUISI
Terindeks DOAJ: 2541-2965

\title{
APAKAH PASUTRI PUAS DENGAN PERNIKAHANNYA? PERANAN NEUROTICISM TERHADAP MARITAL SATISFACTION
}

\section{Katherine Wijaya ${ }^{\bowtie}$, Rianda Elvinawanty, Yulinda Septiani Manurung}

Fakultas Psikologi, Universitas Prima Indonesia, Indonesia

\begin{tabular}{l}
\hline Info Artikel \\
\hline Sejarah Artikel: \\
Disubmit 11 Januari 2020 \\
Direvisi 6 Maret 2020 \\
Diterima 24 Maret 2020
\end{tabular}

Keywords:

Marital Satisfaction,

Neuroticism, Spouses

\begin{abstract}
Abstrak
Setiap pasangan memiliki pengalaman sendiri di dalam pernikahannya. Pernikahan tidak terlepas dengan permasalahan rumah tangga. Permasalahan-permasalahan yang muncul tersebut mampu mempengaruhi kepuasan dalam pernikahan yang dirasakan oleh setiap pasangan. Faktor yang mempengaruhi kepuasan tersebut adalah salah satu trait kepribadian Big Five yaitu neuroticism. Penelitian ini bertujuan untuk melihat hubungan neuroticism dengan marital satisfaction. Penelitian ini merupakan penelitian kuantitatif dengan subjek berjumlah 167 pasangan atau 334 subjek yang dipilih dengan metode purposive sampling. Alat ukur yang dalam penelitian ini adalah Skala Neuroticism dan Skala Marital Satisfaction. Analisis yang digunakan dalam penelitian ini adalah analisis data Pearson Product Moment Correlation. Hasil analisis data menunjukkan $\mathrm{r}=-0.544, \mathrm{p}=.000(\mathrm{p}<0.01$ ), yang menunjukkan terdapat hubungan negatif yang signifikan antara neuroticism dengan marital satisfaction. Hal ini yang berarti bahwa emosi atau tingkat neuroticism pasangan yang tinggi akan menurunkan kepuasan pernikahan yang dirasakan.
\end{abstract}

\begin{abstract}
Every spouse has their own experience in their marriage. Marriage is inseparable from household problems. These problems can influence spouse's satisfaction in their marriage. One of the factors that influence this satisfaction is one of the Big Five personality traits which is neuroticism. This study aims to find relationship between neuroticism and marital satisfaction. This study is a quantitative study with 167 spouses or 334 subjects as sample that was chosen with purposive sampling method. The measuring instruments used are Neuroticism Scale and Marital Satisfaction Scale. Analysis data used is Pearson Product Moment Correlation. The data analysis result showed $r=-0.544, p=.000(\mathrm{p}<0.01)$, means there is a negative relationship between neuroticism and marital satisfaction. This means that the higher emotion or neuroticism level can reduce the marital satisfaction that spouses sense.
\end{abstract}

(C) 2020 Universitas Negeri Semarang 


\section{PENDAHULUAN}

Manusia mengalami banyak
perubahan dan perkembangan dalam kehidupannya, mulai dari masa awal kelahiran hingga kematian. Setiap tahap yang dialami tersebut membuat individu menjadi lebih baik dari tahap sebelumnya. Di antara tahap-tahap tersebut, terdapat tahapan dimana individu mulai mandiri, tidak bergantung kepada orang tua, mencari pasangan dan memiliki kehidupan baru dengan keluarga barunya yang terjadi di dalam masa dewasa awal merupakan masa dimana manusia memulai karier dan menjalin hubungan dengan lawan jenis (Santrock, 2002). Salah satu tugas masa dewasa awal adalah melaksanakan pernikahan dan membina sebuah keluarga. Pernikahan selalu membutuhkan dua individu yang bekerjasama agar keluarga harmonis. Namun, dalam setiap pernikahan terdapat pemasalahan-permasalahan yang tidak dapat dihindari hingga mampu mempengaruhi kepuasan yang dirasakan oleh pasangan. Permasalahan-permasalahan tersebut dapat muncul salah satunya dikarenakan emosiemosi negatif yang dimiliki oleh pasangan. Permasalahan serupa juga muncul di tempat penelitian yang dituju. Emosi-emosi negatif seperti rasa cemburu terhadap pasangan ataupun ketidakstabilan dalam mengontrol emosi.

Perceraian pada tahun 2017-2018 di Kota Medan berada pada sekitar 2.400 kasus dan lebih dari $50 \%$ dari kasus tersebut dikarenakan oleh faktor ekonomi (Tribun, 2018). Pada tahun 2019, di Kota Medan terdapat 3.457 kasus perceraian. Angka ini melonjak dari tahun sebelumnya (Kaldera, 2020). Banyak faktor yang menyebabkan angka perceraian terus meningkat. Faktor utama yang sering dikeluhkan oleh setiap pasangan suami istri yang sedang dimediasi ataupun menunggu pengutusan pengadilan pada umumnya terkait permasalahan kurangnya komunikasi yang diakibatkan karena perubahan sikap pasangan dan penggunaan sosial media. Faktor komunikasi dan ekonomi merupakan salah satu dimensi yang menentukan puas atau tidaknya suatu pernikahan (Rumondor, 2013). Menurut penelitian yang dilakukan oleh Herawati dan Widiantoro (2019) pada pasangan di Kabupaten Rokan Hulu, ditemukannya bahwa tingkat kepuasan pernikahan yang dirasakan masyarakat di kabupaten tersebut berada dalam kategori yang rendah. Sayehmiri, Kareem, Abdi, Dalvand dan Gheshlagh (2020) menyatakan interaksi atau komunikasi negatif yang berhubungan dengan emosiemosi negatif dapat mempengaruhi kepuasan yang dirasakan oleh pasangan.

Marital satisfaction merupakan faktor penting dalam hubungan pasangan yang dapat mempengaruhi secara positif peningkatan kepribadian dan kesehatan mental (Samani, Jafari, Abolwasemi, Avani, dan Fatemi, 2016). Hal ini berarti bahwa jika pasangan merasa senang atau bahagia, mereka mencapai kepuasan dalam pernikahan. Namun, jika terdapat permasalahan dalam pernikahan atau keinginan yang tidak dipenuhi oleh pasangan, mereka tidak mampu mencapai kepuasan tersebut.

Rumondor (2013) mengungkapkan bahwa marital satisfaction terdiri dari 9 (sembilan) dimensi, yaitu 1) Komunikasi, komunikasi yang dijalin oleh pasangan mampu memberi kepuasan kepada pasangan,

2) Keseimbangan pembagian peran, setiap pasangan berbagi peran dengan seimbang, 3) Kesepakatan, pasangan mampu berdiskuis mengenai permasalahan dalam keluarga dan mengambil keputusan yang tepat, 4) Keterbukaan, pasangan dapat mengungkapkan perasaan, isi pikiran, dan informasi secara terbuka kepada pasangannya, 5) Keintiman, pasangan mampu menghabiskan waktu berdua tanpa adanya kehadiran teman atau anggota keluarga lainnya, 6) Keintiman sosial dengan relasi, pasangan dapat menghabiskan waktu dengan melakukan kegiatan bersama dengan pasangan dan teman atau keluarga, 7) 
Seksualitas, pasangan dapat menentukan aktivitas seksual tanpa adanya paksaan dari pasangannya dan kesetian berhubungan seksual hanya dengan pasangannya saja, 8) Finansial, pasangan mampu memenuhi kebutuhan rumah tangga dari segi materiil, 9) Spiritual, pasangan merasakan pemenuhan kebutuhan spritiual yang cukup selama hubungan pernikahan.

Salah satu dimensi marital satisfaction yaitu komunikasi memiliki hubungan dengan salah satu trait kepribadian Big Five yaitu neuroticism. Najarpourian, Fathizadeh, Etemadi, Ghamesi, Abedi, dan Bahrami (2012), dalam penelitiannya menunjukkan tingginya kepribadian neuroticism yang dimiliki pasangan dapat mempengaruhi penurunan komunikasi antar pasangan. Sehingga, pasangan tersebut mengalami penurunan dalam kepuasannya dalam pernikahan.

Trait kepribadian Big Five terdiri dari lima yaitu neuroticism $(\mathrm{N})$, extraversion $(\mathrm{E})$, opennes (O), agreebleness (A), dan conscientiousness $(\mathrm{C})$ yang disingkat menjadi OCEAN (Goldberg dalam Cervone \& Pervin, 2013). Salah satu trait kepribadian Big Five yaitu neuroticism didefinisikan sebagai ketidakstabilan emosional individu. Beberapa individu memiliki rasa takut terhadap beberapa objek dan mungkin mengalami obsesi atau gejala impulsif (Ryckman, 2008). Purna dan Prawitasari (2019) mengungkapkan bahwa individu dengan trait kepribadian neuroticism cenderung kurang efektif dalam meregulasi emosi mereka. Mereka juga tidak percaya dengan orang lain yang mampu mengubah emosi negatif mereka, dan mereka percaya bahwa emosi negatif yang dimiliki sangat kuat dan sulit untuk mengontrol diri mereka.

Ryckman (2008) mengungkapkan adanya 5 (lima) ciri neuroticism, yaitu: 1) Insecurity, rasa tidak percaya diri, penuh dengan perasaan negatif mengenai suatu hal, 2) Fear, rasa takut dan cemas, 3) Instability, ketidakstabilan emosi dan temperamen yang buruk, 4) Emotionally, melakukan segala sesuatu dengan emosi, 5) Envy, kecemburuan dan rasa iri serta dengki.

Berdasarkan latar belakang tersebut, penulis merumuskan sebuah hipotesis yaitu adanya hubungan negatif antara neuroticism dan marital satisfaction pada pasangan suami istri. Tujuan penulisan ini untuk mengetahui hubungan antara neuroticism dengan marital satisfaction pada pasangan suami istri.

Manfaat dari penelitian ini adalah penelitian ini dapat menjadi masukan yang berguna bagi pasangan suami istri dan dapat menambah wawasan untuk mencapai kepuasan pernikahan yang tinggi. Manfaat lain dari penelitian ini adalah dapat membantu Ketua RT/Ketua RW menjadi mediator dalam penyelesaian masalah pernikahan terutama tingkat kepuasan pernikahan pasangan yang tinggal di daerahnya.

\section{METODE}

Populasi dalam penelitian ini adalah pasangan suami istri yang telah menikah minimal 10 tahun dan memiliki anak dan kepribadian neuroticism. Penelitian ini dilakukan di salah satu kelurahan di kota Medan. Sampel dalam penelitian ini diambil dengan menggunakan teknik purposive sampling yaitu teknik penentuan sampel dengan menggunakan kriteria atau pertimbangan tertentu (Sugiyono,n2017). Sampel yang didapatkan melalui metode pengambilan sampel ini adalah sebanyak 167 pasangan atau 334 subjek sesuai dengan ketentuan kriteria yang telah ditetapkan.

Menurut Buecker, Maes, Denissen, dan Luhmann (2020), neuroticism berhubungan dengan peningkatan reaksi terhadap stressor sosial. Individu dengan neuroticism yang tinggi lebih sensitif terhadap penolakan sosial. Namun, definisi operasional dari neuroticism yang digunakan dalam penelitian ini merupakan salah satu dari bagian kepribadian Big Five yang merupakan 
emosi negatif seperti cemas, gelisah, dan sedih. Pandangan Ghahremani, Doulabi dan Eslami (2019) terhadap marital satisfaction adalah sebuah peran besar dalam konsolidasi dan ketahan pernikahan. Marital satisfaction merupakan kunci dari kepuasan dalam hidup yang menunjukkan tingkat kerjasama antara pasangan dan menunjukkan kebahagiaan mereka. Namun dalam penelitian ini definisi operasional dari marital satisfaction adalah perasaan bahagia dan rasa terpenuhi secara jasmani dan rohani yang dirasakan oleh pasangan dalam pernikahan mereka.

Penelitian ini menggunakan metode kuantitatif dan alat pengumpulan yang digunakan adalah Skala Likert. Skala Likert terdiri dari pernyataan yang bersifat favourable dan unfavourable dengan empat alternatif jawaban untuk setiap butir pertanyaan sehingga dapat menghindari kemungkinan jawaban di tengah-tengah. Skala Marital Satisfaction terdiri dari 41 aitem dengan 19 aitem favourable dan 21 aitem unfavourable. Skala ini mengacu pada teori yang diungkapkan Rumondor (2013) yang meliputi 9 (sembilan) dimensi, yaitu keseimbangan peran, komunikasi, keterbukaan, kesepakatan, keintiman sosial dengan relasi, finansial, seksualitas, keintiman, dan spiritualitas. Skala Neuroticism terdiri dari 35 aitem dengan 17 aitem favourable dan 18 aitem unfavourable. Skala ini mengacu pada teori yang diungkapkan Ryckman (2008) yang meliputi 5 (lima) ciri, yaitu insecurity, fear, instability, emotionally, dan envy.

Data penelitian kemudian dilakukan uji asumsi klasik yang terdiri dari uji normalitas sebaran dan uji linearitas hubungan. Selanjutnya dilakukan uji hipotesis antara neuroticism dan marital satisfaction untuk mengetahui apakah hipotesis dari penelitian ini diterima atau tidak. Uji hipotesis yang digunakan dalam penelitian ini adalah Pearson Product Moment. Melalui data penelitian, peneliti mencari sumbangan efektif neuroticism terhadap marital satisfaction untuk mengetahui seberapa besar pengaruh neuroticism terhadap marital satisfaction. Semua pengujian data dilakukan menggunakan software pengolah data.

\section{HASIL DAN PEMBAHASAN}

Berikut adalah data deskriptif yang didapatkan dari setiap variabel:

Tabel 1

Hasil Analisis Deskriptif

\begin{tabular}{lcccc}
\hline \multicolumn{1}{c}{ Variabel } & Min & Max & Mean & SD \\
\hline $\begin{array}{l}\text { Marital } \\
\text { Satisfaction }\end{array}$ & 77 & 162 & 114.04 & 16.389 \\
Neuroticism & 58 & 140 & 101.40 & 13.471 \\
\hline
\end{tabular}

Uji asumsi klasik dilakukan sebelum pengujian hipotesis dilakukan. Uji ini dilakukan untuk mengetahui apakah adanya penyimpangan data yang diperoleh dari alat pengumpulan data. Uji asumsi klasik terdiri dari uji normalitas sebaran dan uji linearitas hubungan. Uji normalitas sebaran menggunakan uji Kolmogorov Smirnov. Data terdistribusi normal jika $\mathrm{p}>0.05$ (Priyanto, 2010).

Tabel 2

Uji Normalitas Sebaran

\begin{tabular}{lc}
\hline \multicolumn{1}{c}{ Variabel } & Sig. \\
\hline Marital Satisfaction & 0.090 \\
Neuroticism & 0.215 \\
\hline
\end{tabular}

Berdasarkan hasil pada Tabel 2, tampak bahwa data yang didapatkan pada variabel marital satisfaction dan variabel neuroticism terdistribusi normal. Selanjutnya, dilakukan uji linearitas hubungan untuk mengetahui derajat hubungan antara variabel apakah kedua variabel memiliki hubungan yang linear atau tidak dalam penelitian ini. Uji linearitas hubungan ini merupakan salah satu syarat dalam pengujian analisis korelasi data Pearson Product Moment. Kriteria uji linearitas hubungan adalah apabila nilai signifikansi $\mathrm{p}<0.05$ maka dinyatakan memiliki derajat hubungan yang linear. 
Tabel 3

Uji Linearitas Hubungan

\begin{tabular}{lc}
\hline \multicolumn{1}{c}{ Variabel } & Sig. \\
\hline $\begin{array}{l}\text { Marital Satisfaction } \\
\text { Neuroticism }\end{array}$ & 0.000 \\
\hline
\end{tabular}

Berdasarkan hasil pada tabel 3, dapat dikatakan variabel neuroticism dan variabel marital satisfaction memiliki hubungan linear. Hal ini dapat dilihat dari nilai signifikansi $\mathrm{p}<0.01$, maka dapat disimpulkan bahwa variabel neuroticism dan variabel marital satisfaction memiliki hubungan linear dan dapat dilakukan uji analisis korelasi data Pearson Product Moment untuk menguji hipotesis. Hipotesis dalam penelitian ini adalah hubungan negatif antara neuroticism dengan marital satisfaction.

Tabel 4

Uji Korelasi Neuroticism dengan Marital Satisfaction

\begin{tabular}{ccc}
\hline & \multicolumn{1}{c}{$\begin{array}{c}\text { Marital } \\
\text { Vatisfaction }\end{array}$} \\
\cline { 2 - 2 } Variabel & $R$ & Sig. (p) \\
\cline { 2 - 3 } Neuroticism & -0.544 & 0.000 \\
\hline
\end{tabular}

Berdasarkan hasil analisis dari korelasi antara neuroticism dan marital satisfaction, diperoleh bahwa koefisien korelasi Pearson Product Moment sebesar 0.544 dengan signifikansi $\mathrm{p}<0.01$. Hal ini berarti bahwa adanya korelasi negatif yang sangat signifikan antara neuroticism dengan marital satisfaction, dan hubungan ini dikategorikan sedang karena berada pada rentang 0.40-0.599 (Priyatno, 2010). Berdasarkan hasil analisis korelasi tersebut, maka hipotesis yang diajukan dalam penelitian ini yaitu terdapat hubungan negatif antara neuroticism dan marital satisfaction pada pasangan suami istri diterima dan dapat dinyatakan bahwa terdapat hubungan negatif yang sedang dan signifikan antara neuroticism dengan marital satisfaction.

Hasil ini sejalan dengan penelitian sebelumnya yang dilakukan oleh Khoshdast, Jalali, dan Kakavand (2016) dalam penelitiannya yang menguji hubungan antara neuroticism dengan marital satisfaction pada 300 pasangan suami istri di Qazvin. Penelitian ini menunjukkan bahwa terdapat hubungan korelasi yang negatif antara neuroticism dengan marital satisfaction. Penelitian lain juga dilakukan oleh Shahmoradi, Maleki, Maleki, Shahmoradi, dan Foumany, (2014) yang menunjukkan adanya hubungan negatif yang signifikan antara neuroticism dan marital satisfaction. Hal ini dapat berari bahwa individu dengan neuroticism lebih sulit mengontrol impulsivitasnya and hal tersebut dapat menyebabkan perselisihan dan konflik antar pasangan dan akhirnya akan mengurangi marital satisfaction antara pasangan. Javanmard dan Garegozlo (2013) menemukan bahwa pasangan dengan tingkat neuroticism yang tinggi mendeskripsikan hubungan pernikahan yang tidak memuaskan.

Tabel 5

Sumbangan Efektif

\begin{tabular}{lc}
\hline \multicolumn{1}{c}{ Variabel } & $R$ Square \\
\hline Marital Satisfaction & 0.296 \\
Neuroticism & \\
\hline
\end{tabular}

Pada tabel 5 Sumbangan Efektif tersebut, dapat disimpulkan bahwa diperoleh koefisien determinasi $\left(\mathrm{R}^{2}\right)$ sebesar 0.296. Hasil tersebut menunjukkan bahwa neuroticism mempengaruhi marital satisfaction sebesar 29.6 persen dan sebesar 70.4 persen dipengaruhi oleh faktor lain seperti conscientiousness, pemaafan, religiusitas, bersyukur, konflik peran ganda, kesejahteraan psikologis, self-disclosure, empati, komitmen cinta, kemampuan finansial, tingkat pendidikan, dan kematangan emosi.

Rasa marah yang tinggi dirasakan oleh pasangan dapat menjadi salah satu permasalahan dalam pengendalian emosinya. Rasa marah tersebut dapat menyebabkan peningkatan agresivitas dan ketidak stabilan dalam diri pasangan. Peningkatan agresivitas ini sangat mempengaruhi hubungan antara pasangan dan kepuasan terhadap pernikahannya (Samani et al, 2016). 
Pernyataan yang sama juga dikemukakan oleh Khoshdast et al, 2016, yang menyatakan bahwa rasa takut, kesedihan mendalam, dan kebencian, yang merupakan salah satu bagian dari neuroticism, dapat menyebabkan permasalahan dalam komunikasi terutama antar pasangan. Komunikasi merupakan salah satu dimensi utama dalam marital satisfaction. Sehingga apabila hal tersebut menjadi permasalahan antar pasangan, maka pasangan dapat merasakan ketidakpuasan dalam kehidupan pernikahan mereka. Fenomena yang ditemukan di tempat penelitian sejalan dengan teori yang dikemukakan di atas, seperti rasa takut yang dimiliki pasangan akan masa lalunya membuat ia sulit untuk berkomunikasi atau membicarakan dirinya sendiri dan juga agresivitas pasangan dalam bentuk verbal yang membuat pasangannya takut untuk membicarakan permasalahan yang terjadi dalam rumah tangga mereka. Hal ini menyebabkan pasangannya merasa tidak nyaman dalam pernikahannya, sehingga sulit mencapai kepuasan pernikahan yang tinggi.

Implikasi dari penelitian ini terhadap peneliti selanjutnya adalah dilakukannya penelitian yang serupa di daerah lain untuk mendapatkan gambaran yang lebih mengenai neuroticism dengan marital satisfaction. Dalam pelaksanaannya, peneliti lain dapat memakai variabel bebas lainnya, seperti conscientiousness, pemaafan, religiusitas, bersyukur, konflik peran ganda, dan lain-lain.

Keterbatasan dari penelitian ini adalah penelitian saya hanya melibatkan subjek dari satu kelurahan di Kota Medan. Penelitian ini juga terbatas karena adanya beberapa pasangan suami istri yang tidak bersedia menjadi subjek dari penelitian ini.

\section{SIMPULAN}

Hasil penelitian yang telah dilakukan peneliti adalah adanya hubungan negatif yang signifikan antara marital satisfaction dan neuroticism. Hal ini berarti bahwa semakin tinggi tingkat neuroticism maka akan semakin rendah tingkat marital satisfaction, dan sebaliknya, semakin rendah tingkat neuroticism maka akan semakin tinggi tingkat marital satisfaction.

Saran peneliti bagi pasangan suami istri adalah untuk menurunkan kecemasan, kecemburuan dan meningkatkan kepercayaan terhadap diri sendiri karena hal tersebut dapat membantu komunikasi dan interaksi antara pasangan yang mampu meningkatkan marital satisfaction yang dimiliki oleh pasangan. Kepala lingkungan juga disarankan untuk membantu pasangan suami istri yang tinggal di daerah yang ia pimpin agar pasangan tersebut mampu meningkatkan marital satisfaction dalam kehidupan pernikahan mereka.

\section{DAFTAR PUSTAKA}

Buecker, S., Maes, M., Denissen, J. J. A., \& Luhmann, M. (2020). Loneliness and the Big Five Personality Traits: A Metaanalysis. European Journal of Personality, 34(1), 8-28. doi:10.1002/per.2229

Cervone, D. \& Pervin, L. A. (2013). Personality: Theory and Research Twelfth Edition. USA: John Wiley \& Sons, Inc.

Ghahremani, F., Ahmadi Doulabi, M., \& Eslami, M. (2019). The correlation between marital satisfaction and childbearing characteristics in women in Tehran. International Journal of Adolescent Medicine and Health, 1-9. doi:10.1515/ijamh-2019-0018

Herawati, I., \& Widiantoro, D. (2019). Kebersyukuran dan Kemaafan Terhadap Kepuasan Pernikahan. Al-Hikmah: Jurnal Agama dan Ilmu Pengetahuan, $16(2)$, 108-119. doi:10.25299/jaip.2019.vol16(2).3782

Javanmard, G. H., \& Garegozlo, R. M. (2013). The Study of Relationship Between Marital Satisfaction and 
Personality Characteristics In Iranian Families. Procedia - Social and Behavioral Sciences, 84, 396-399. doi:10.1016/j.sbspro.2013.06.573

Kaldera. (2020, 18 Januari). Cerai di Medan Tembus 3.457 Kasus, Medsos Awal Selingkuh. Kaldera.id. Diakses dari https://kaldera.id/cerai-di-medantembus-3-457-kasus-medsos-awalselingkuh/

Khoshdast, F. A., Jalali, M. R., \& Kakavand, A. R. (2016). Relationship between the personality traits, defense mechanisms and marital satisfaction of elementary school students' parents. IIOAB Journal, 7(10), 31-37.

Najarpourian, S., Fatehizadeh, M., Etemadi, O., Ghasemi, V., Abedi, M. R., \& Bahrami, F. (2012). Personality Types and Marital Satisfaction. Interdisciplinary Journal of Contemporary Research in Business, 4(5), 372-383. ijcrb.webs.com

Priyatno, D. (2010). Teknik Mudah dan Cepat Melakukan Analisis Data Penelitian dengan SPSS. Yogyakarta: Gaya Media.

Purna, R. S., \& Prawitasari, J. E. (2019). Trait Relations: Openness, Conscientiousness, Extraversion, Agreeableness, Neuroticism with Teacher Emotion Regulation. International Journal of Humanities and Social Science, 9(3), 33-40. doi:10.30845/ijhss.v9n3p5

Rumondor, P. C. B. (2013). Pengembangan Alat Ukur Kepuasan Pernikahan Pasangan Urban. Humaniora, 4(2), 1134. doi:10.21512/humaniora.v4i2.3554
Ryckman, R. M. (2008). Theory of Personality, Ninth Edition. USA: Thomson Wadsworth.

Santrock, J. W. (2002). Life-Span Development: Perkembangan Masa Hidup, edisi kelima. Jakarta: Erlangga.

Samani, L. N., Jafari, F., Abolwasemi, J., Avani, S. T., \& Fatemi, N. S. (2016). Marital Satisfaction and Character. International Journal of Biology, Pharmacy and Allied Sciences (IJBPAS), 5(4), 907-918.

Sayehmiri, K., Kareemnajar, K. I., Abdi, K., Davland, S., \& Gheshlagh, R. G. (2020). The Relationship Between Personality Traits and Marital Satisfaction: A Systematic Review and Meta-analysis. BM,C Psychol, 8(15), 1-8. doi:10.1186/s40359-020$0383-\mathrm{z}$

Shahmoradi, G., Maleki, E., Maleki, T., Shahmoradi, Z., \& Foumany, G. H. E. (2014). Relationship between Marital Satisfaction and Personality Characteristics on the basis of MyersBriggs Inventory and Big Five Questionnaire. Journal of Educational and Management Studies, 4(4), 787790.

Siswanto., Susila., \& Suyanto. (2017). Metodologi Penelitian Kombinasi Kualitatif-Kuantitatif Kedokteran \& Kesehatan. Klaten: BOSSSCRIPT.

Tribun Medan. (2018, April 12). Angka Perceraian di Kota Medan Sangat Tinggi, Dzulmi Eldin Mengaku Prihatin. Tribun Medan. Diakses dari https://medan.tribunnews.com/2018/0 4/12/angka-perceraian-di-kotamedan-sangat-tinggi-dzulmi-eldinmengaku-prihatin?page $=$ all 